\title{
SOME ASPECTS OF PUBLIC ADMINISTRATION AND PUBLIC BUDGETING OF THE SLOVAK REPUBLIC
}

\author{
Jana Džun้ová*
}

\begin{abstract}
Article presents characteristics of public administration of the Slovak Republic. The first part of article is focused on structure of public administration, with an emphasis on territorial self-government. The second part of article is focused on the budget of territorial self - government, with some aspects of fiscal decentralization. At the end of issue are presented the main conclusions, with the proposal for improvement.
\end{abstract}

Key words: public administration, territorial self - government, budget, fiscal decentralization

\section{INTRODUCTION}

Continental system of public administration structure of the Slovak Republic is characterised by a dual system of hierarchy, where there is no relation of superiority or inferiority, and individual authorities and institutions operating at different organizational levels shall cooperate with each other $^{1}$. In this paper we would like to focus on the functioning of the local self-government with a special emphasis on the budgetary area. In order to achieve the above-mentioned goal, it is important to highlight the various

\footnotetext{
PhDr. - full time PhD. student, Department of Economics and Management of Public Administration, Faculty of Public Administration, Pavol Jozef Šafárik University in Košice.

1 Palúš Igor, Štátne právo porovnávacie, Košice: UPJŠ Košice, 2002, 207-209.
} 
aspects of the fiscal decentralization related to the financial resources for municipality and local self-government.

\section{PUBLIC ADMINISTRATION STRUCTURE OF THE SLOVAK REPUBLIC}

Public administration in Slovakia serves as a tool for execution of public power, which is, in general, exercised in the form of state power or other public powers (decentralised forms of public power) ${ }^{2}$.

\section{State power}

State power can be further subdivided into three branches: executive, legislative and judicial power, while the Constitution of the Slovak Republic provides the definition of each of them. As regards legislative power, Chapter V of the Constitution states that The National Council of the Slovak Republic is the sole constitutional and legislative body of the Slovak Republic ${ }^{3}$. In practice it means that, in accordance with the Constitution, the National Council is the one and only body empowered to pass all types of law.

Chapter VI of the Constitution is devoted to the second branch of state power - executive power - represented by the President and by the Government of the state. Thus, the President is the head of state and represents the Slovak Republic outwardly, while the Government is the supreme body of executive power.

The last branch, judicial power, is provided by the Chapter VII of the Constitution which states that Justice in Slovakia is administrated by the Constitutional Court of the Slovak Republic, an independent judicial body charged with the protection of constitutionality, and system of courts consisting of the Supreme Court of the Slovak Republic and other courts 5 .

2 Palúš Igor, Jesenko Michal, Olexa Lukáš, Ondrová Júlia, Ústavné právo Slovenskej republiky, Košice: UPJŠ Košice, 2016, 245-247.

3 Chapter V. Article 72 of Constitution of the Slovak Republic.

4 Chapter VI. Article $102 \$ 1$ a), Article 108 of Constitution of the Slovak Republic.

5 Chapter VII. Article 141, of Constitution of the Slovak Republic. 


\section{Other public powers}

Other source of public power, or the so-called decentralized public power, is exercised by local self-government units comprising of municipality, as the basic element of local self-government which is represented by mayor and municipal council deputies, and of higher territorial unit represented by chairman and member of the assembly ${ }^{6}$. The next section of this paper examines public administration as one of the subjects executing the public power through its basic subsystems.

\subsection{PUBLIC ADMINISTRATION AND ITS SUBSYSTEMS}

When talking about public administration itself, there are many aspects to be discussed (for example, the ambiguity of the term administration, different theoretical approaches, or the extent to which public administration can be regarded as an academic discipline etc.).

We need to establish certain baselines to delimitate the concept of public administration, so we can embrace all the possible interpretations of this term. Three different approaches to public administration have been proposed to cover its scope: (1) public administration as academic discipline, (2) public administration as study programme within the area of higher education, and (3) public administration in practice, i.e. the network of offices and agencies charged with executing state policy ${ }^{7}$. As far as the practical aspect is concerned, we refer to the activity whose purpose is public service, that is, an activity carried out for the public interest by applying predefined political principles ${ }^{8}$.

\section{State Administration}

Performance of public administration is the main activity of the state that within its executive power, provided by state administration bodies.

6 Palúš Igor, Jesenko Michal, Olexa Lukáš, Ondrová Júlia, Ústavné právo Slovenskej republiky, Košice: UPJŠ Košice, 2016, 246. $9-10$.

Klimovský Daniel, Základy verejnej správy, Bratislava: Wolters Kluwer SK, 2014,

8 Hughes, Owen, E., Public management and administration, an Introduction, New York: Palgrave Macmillan, 2003, 17-20. 
The state administration system in Slovakia consists of central state administration bodies (government and ministries) and local state administration bodies (district offices). Competencies and powers of the central state administration bodies are defined by the Act No. 575/2001 Coll. on the Organization of the Activity of the Government and on the Organization of the Central State Administration while the competencies and powers of local state administration are regulated by the Act No. 180/2013 Coll. on the organisation of the local state administration as amended.

\section{Self-government}

Self-government represents the second component of public administration system, but when compared to state administration, it differs in methods and forms of action to perform its activities. The basic difference lies mainly in the fact that self-government uses means of a non-state power character. However, it does not prevent the cooperation between these two authorities, both having as the purpose effective conduct of public interest activities?. Self-government is then the form of a public corporation with its own self-administrative power that regulates basically itself. The most common forms of self-government that make part of the Slovak organizational structure are: interest, territorial, and special form of self-government ${ }^{10}$.

Structure of the interest self-government is conceived as a group of people of non-specified number who share a common profession, resp. other common interes $\mathrm{t}^{11}$. In practice, different professional organizations, or chamber with compulsory membership, as well as 'liberal professions' are included here. In connection with the concept of self-government and, therefore, public administration, it is the main occupation of the above-mentioned organizations to regulate professions, or functions within a certain professional area which might have an impact on a whole society ${ }^{12}$. As we mentioned

9 Hendrych Dušan a kol., Správní právo, obecná čast, Praha: C.H.Beck, 2006, 160-162.

10 Klimovský Daniel, Základy verejnej správy, Bratislava: Wolters Kluwer SK, $2014,242$.

11 Tej Juraj, "Správa a manažment", Univerzitná knižnica Prešovskej univerzity (2011): 39. October 23, 2017 http://www.pulib.sk/elpub2/FM/Tej2/index.html : http:// www.pulib.sk/elpub2/FM/Tej2/index.html

12 Sládeček, Vladimír, Obecné správní právo, Praha: Wolters Kluwer, 2005, 255-256. 
previously, one of the basic features of interest self-government is compulsory membership, characterised by its exclusivity, and its own regulations. In the cases of non-compliance with the regulations and/or failure to fulfil duties and requirements that are consistent with the public interest, interest self-government may apply particular coercive measures at any time ${ }^{13}$.

Special self-government, as part of the Slovak self-government structure, has a form of association consisting of mixed bodies, where, some of the activities are exercised, on one side, by self-government and on the other side, there are other public authorities. In particular, that is the case of higher public educational institutions which are subject to the state supervision, but there some areas of decision-making where they act as self-regulatory bodies. It means that they regulate decisions regarding, for example, conditions of admission to study, financial management, or management of their assets etc. The Slovak court system, namely the Judicial Council of the Slovak republic, has the same organizational structure of special selfgovernment and it shall decide independently on certain issues, such as assignment and transfer of judges, etc ${ }^{14}$.

In general, more attention is devoted to territorial self-government, as it is considered to be one of the characteristic principles of democratic states. The importance of the territorial self-government is reinforced by the fact that the Slovak republic is one of the countries respecting the European Charter of Local Self-Government. By doing so, Slovakia has agreed to comply with its basic provisions that recognise local self-government to be the cornerstone of every democratic system that guarantees an effective management of its own affairs ${ }^{15}$.

The proper definition of local self-government is provided by the Chapter IV of the Constitution of the Slovak Republic, under which local self-government consists of the municipality as its basic organizational element, and the other one being higher territorial unit. Municipality and higher territorial unit represent independent territorial and administrative

13 Klimovský Daniel, Základy verejnej správy, Bratislava: Wolters Kluwer SK, 2014, 248.

14 Machajová Jozefína a kol., Všeobecné správne právo, Bratislava: Poradca podnikatel'a, spol. s.r.o., 2007, 120-122.

15 The Preamble of The European Charter of local self-government. 
units of the Slovak Republic, comprising persons with permanent residence on its territory, who have status of legal persons and independently manage their own property and financial resources while they finance their needs primarily from their own revenues or from state subsidies ${ }^{16}$.

\section{Bodies governed by public law (public corporations)}

The system of public administration in Slovakia comprises, in addition to state administration and self-government, a body governed by public law, referred to as 'public corporation', where the freedom of association represents one of the democratic principles of the state. In general, we understand the term corporation as an association of persons pursuing a certain aim whose joint efforts are fundamental to achieve this aim. Public corporation has legal personality, but the following criteria need to be met so we can consider it to be public: in needs to be created by legislature, to be financed, fully or partially, from the public budgets, and it should pursue activities beneficial for the whole society by providing specific public services. Moreover, one further important feature is that public corporation might have certain elements of public authority ${ }^{17}$. It follows that, if public corporation is included in the organizational system of public administration and its activities are of public character, public administration is therefore an essential for the exercise of public power.

The next chapter is devoted to the area of state budget and its characteristics, since all the activities exercised by public institutions and bodies are linked to the allocation and distribution of financial resources.

\section{PUBLIC ADMINISTRATION BUDGET OF THE SLOVAK REPUBLIC}

The question of public budget, i.e. state budget, has already been discussed by many authors and it has been analysed from different angles. In the most general meaning, state budget is perceived as a central financial fund consisting of the resources necessary for the state to perform its

16 Article 64-65 of Constitution of the Slovak Republic.

17 Škultéty Peter, Kaššák Rastislav, Správne právo hmotné: všeobecná čast', Bratislava: Veda, 2014, 21-22. 
functions. From an economic (or accounting) perspective, these are revenues and expenditures of the state incurred during a certain period of time. Legally speaking, state budget represents main financial contribution to public budgets, and it is the most important instrument of state financial policy that governs further development of the country. Within the social function of the state, state budget is the instrument for distribution of preallocated financial resources to certain groups of population, in order to guarantee their safety or minimum acceptable living standards ${ }^{18}$.

The legal basis upon which state budgets are defined is proposed by the Act No. 523/2004 Coll. on Budget Rules of the Public Service and of Change and Amendment of Some Acts (hereinafter referred to as Act on Budget Rules of the Public Service). Under this law, state budget is defined as follows: 'The budget of public service is a central economical instrument of the financial policies of the state. It is drawn up every year for at least three budget years'. In addition to the state budget, as a financial tool of central state administration, the system of public budgets is comprised of budgets of other public administration bodies, such as local self-government authorities (municipalities and higher territorial units, as well as organizations established by them) ${ }^{19}$. The next chapter of this paper deals with the most important features of the state budget, municipal budget, and self-government budget.

\subsection{STATE BUDGET AND LOCAL SELF-GOVERNMENT BUDGET}

The issue of state budget and budget of local self-government (that includes municipal budget and budget of higher territorial unit) is too complex, so that it cannot be approached only from the theoretical point of view; there is also a need to consider potential and unpredictable changes in the external environment that may occur.

Because of the possible changes in the amount of estimated expenses, state budget is adopted by means of law for a limited period of time.

18 Sivák Rudolf, Financie, Bratislava: Wolters Kluwer, 2015, 319-320.

$19 \$ 4(1), \$ 3$ (1) b), $\$ 3$ (2) of Budget Rules of the Public Service and of Change and Amendment of Some Acts. 
Namely, there are two national legislations governing public budgets: the first one is the above-mentioned Act on Budget Rules of the Public Service which deals with state budget, while the budget of local self-government is referred to in the Act No. 583/2004 Coll. on Budget Rules of the Regional Self-Administration and of Change and Amendment of Particular Acts (hereinafter referred to as in Act on Budget Rules of the Regional Self-Administration).

\section{State budget}

The procedures for drawing up the state budget are governed by the Act on Budget Rules of the Public Service. Results derived from both microeconomic and macroeconomic analysis, forecasts, and estimates for main fiscal indicators serve to draft state budget law that is submitted by the Government of the Slovak republic and its finalized version is approved by the National Council of the Slovak republic for a respective year. It can be said that state budget is established by law, and this law is to be considered the highest legal power as it governs specific state policies. Every state budget law should contain, regardless of year of application, statement of revenues and expenditures of the state for the current financial year, which shall be the same as the calendar year, together with maximum value of budget deficit or minimum value of budgetary surplus. Specific information regarding the above mentioned financial indicators are contained in the annex to this Act. Moreover, the Act contains expenditures for the repayment of costs of transferred performance of state service to municipalities and higher territorial units as well as obligational indices of state budget that may be amended during the financial year. It is a condition, that amendments made to the Act of State Budget may not exceed the overall cost by more than $1 \%{ }^{20}$.

In practice, it may happen that representatives of the Slovak executive and legislative power do not reach an agreement. In the case that bill of state budget for the following year is not approved by the national council by December 31st of the current budget year, budgetary management is administrated by the budgetary provision in the term from January 1st of the budget year to the time when the Act of State Budget for the

20 Act No. 357/2016 Coll. on Public Budget. 
corresponding budget year comes into force, with regard to expenditure restrictions ${ }^{21}$.

Building on the theoretical knowledge, we may conclude that one of basic characteristic features of state budget is being a medium-term financial plan which can be implemented into the practice in such a way that Act of State Budget includes a draft of financial perspective for the next two budget years ${ }^{22}$.

\section{Self-government budget}

Municipal budget and budget of higher territorial unit, as part of the public budget, are governed by the Act on Budget Rules of the Regional Self-Administration that defines budget of local self-government as the basic financial instrument to finance its activities in the corresponding budget year, coinciding with the calendar year ${ }^{23}$.

The fact that municipality and higher territorial unit draw up and implement the budget by themselves is a sign of their financial autonomy. Municipal budget and budget of higher territorial unit contains income and expenditure of self-government and its relationship to legal persons and individuals - entrepreneurs acting in the territory of the municipality or higher territorial unit, including inhabitants living in this territory. Further, this Act also relates to income and expenditure of budgetary organizations and contributory organizations as the part of the public service section established by them. Budget of municipalities with population under 2000 residents may also contain goals and objectives to be achieved within its budget possibilities; the same applies to a municipality where its municipal council decided not include such goals and objectives in the budget ${ }^{24}$.

Therefore, the process of fiscal decentralisation is closely connected to budgetary area of local self-government units, as it has changed the

21 Article $1 \$ 11(1-2)$ of Act on Budget Rules of the Public Service and of Change and Amendment of Some Acts.

22 Article $1 \$ 4(1)(b-c)$ of Act on Budget Rules of the Public Service and of Change and Amendment of Some Acts.

23 Article $1 \$ 3(1)($ b) of Act on Budget Rules of the Public Service and of Change and Amendment of Some Acts.

24 Article $1 \$ 4(1-5)$ of Act on Budget Rules of the Regional Self-Administration and of Change and Amendment of Particular Acts. 
way financial resources are redistributed among municipality and higher territorial unit.

\subsection{FISCAL DECENTRALISATION IN THE SLOVAK REPUBLIC}

Implementation of the new system of financing followed by subsequent decentralization of powers to municipalities and higher territorial units took place in Slovakia between 2002 and 2004 by adoption of the Act No. 416/2001 Coll. on the transfer of some competences from State administration to municipalities and superior territorial units with a view to strengthen democratic principles and increase the autonomy of selfgovernment. Under this Act, municipality gained some of the competencies from state administration bodies, thus strengthening its autonomy on the one hand, and resulting responsibilities connected with increasing expenses on its activities, on the other hand. As response to this situation, the second period of the reform process consisted of fiscal decentralisation which should have provided municipality with financial resources necessary for fulfilling its competencies. The activities that are carried out by municipality or higher territorial unit, but on behalf of the state and under its responsibility, continue to be financed from state subsidies by force of budget chapter of the relevant ministries. Against this background, the purpose of fiscal decentralisation was to reduce dependency of municipality and higher territorial unit on subsidies from the state budget and replace them with tax revenues, thus allowing self-government to independently manage its own financial resources ${ }^{25}$. By introducing such measures, the principal source of financial income for municipality has become local tax revenue paid by its permanent resident ${ }^{26}$.

The process of fiscal decentralisation in the Slovak republic started in 2004, when the legislative package concerning budget incomes of

25 Maruchnič Ján, Čunderlík Lubomír, “Fiškálna decentralizácia v Slovenskej republike“, Medzinárodní a srovnávací právní revue, 14(2005):65. DOI: http://iclr.upol.cz/wpcontent/uploads/2011/03/14_Maruchnic_Jan-Cunderlik_Lubomir-64-77.pdf

26 Horváthová Lenka, "Dopad fiškálnej decentralizácie na miestne rozpočty v SR”, (2009). DOI: http://kvf.vse.cz/storage/1239723298_sb_horvathova.pdf 
self-governments was adopted. Specifically, it was the Act on the budget determination of income tax yields to regional self-government, as well as the government decree regarding distribution of the revenue from shared income tax (under the fiscal decentralisation, part of the revenues from income tax from individuals was allocated to state budget and other part to municipal budget). In addition to the above, the Act regarding local taxes and the Act on budgetary rules of local self-government unit were adopted ${ }^{27}$.

We have reason to believe that the idea of decentralisation of competencies and financial resources to municipality and higher territorial unit was justified from the point of view that independence of municipality and higher territorial unit was enhanced and chance to deliver public goods and services consistent with their own public interest in an autonomous and non-state-controlled way increased. When evaluating the effects of the implemented changes in the system, initial expectations were met only to the extent that introduction of local taxes, and related higher fiscal autonomy, resulted in increase in tax revenues for self-government and it represented a reduction of the burden on public budget. However, the following changes linked to fiscal decentralisation, and the level of involvement of local representative bodies in all aspects of self-government activities, were also expected: more efficient allocation of financial resources and increase of the efficiency when providing public services, more flexible problem solving, higher level of legal and social responsibility ${ }^{28}$.

\section{Some aspects of fiscal decentralisation}

The process of decentralisation regroups three interconnected, political, fiscal, and administrative aspects ${ }^{29}$. Within the framework of political decentralisation various competences were transferred from state

27 Čavojec Jozef, Sloboda Dušan, "Fiškálna decentralizácia a obce”, Conservative Institute M. R. Štefánika, (2005):4-8. November 03, 2017 http://www.konzervativizmus.sk/ upload/pdf/fisk_dec.pdf

28 Horváthová Lenka, "Dopad fiškálnej decentralizácie na miestne rozpočty v SR", (2009). DOI: http://kvf.vse.cz/storage/1239723298_sb_horvathova.pdf

29 Ebel Robert, Yilmaz Serdar, "Concept of fiscal decentralization and worldwide overview”, World Bank Institute Course Intergovernmental Relations \& Local Financial Management World Bank (2004):15. DOI: https://www.researchgate.net/publication/253798443_ Concept_of_fiscal_decentralization_and_worldwide_overview_World_Bank_Institute 
administration to municipality and higher territorial unit, and measures regarding their financing were subsequently adopted as part of the fiscal decentralisation aspect.

According to the above-mentioned authors, administrative aspect of the process includes the creation of appropriate conditions that enable selfgovernment a smooth exercise of its competences in order to improve the delivery of public services. It is not easy to manage such a complex process and, therefore, some deficiencies can be observed in each of the aspects. To give some examples, we can mention the problems connected with implementation of decentralisation measures, such as the lack of cooperation between the authorities involved (i.e. public administration bodies and representatives of self- government), unresolved property-law relationships, as well as disproportionate number of public functions transferred to self-government. With a view to overcome these deficiencies, government adopted a specific resolution, but it was never applied into practice ${ }^{30}$.

Although the so-called Competence Act was adopted to regulate the transfer of approximately 400 powers and competencies in 16 different areas, it was not concerned with the real and actual conditions in different municipalities and regions. Moreover, no detailed analysis regarding the $c a-$ pacity of self-government to handle the transfer was made prior to its adoption.

When the subsidies from state budget were cancelled and municipality started to finance its needs primarily from the local tax revenue, all municipalities reached the same level of development regardless of their size and population $^{31}$. Even though, there is still a risk that municipality would not be able to meet its budget requirements as it cannot guarantee the compliance with tax obligations of taxpayers for a variety of reasons, one of them being an unbearable tax burden that might lead to the problems with tax collecting. On this basis, residents of municipality might decide to opt for 'foot voting' which means that they would look for a place for living with the lowest tax rate. Such an action might have a negative economic and

30 Nižňanský Viktor, Hamalová Marta, “Decentralizácia a Slovensko” (2013):45. November 05, 2017 http://www.komunal.eu/images/Decentraliz\%C3\%A1cia_a_Slovensko.pdf

31 Čavojec Jozef, Sloboda Dušan, "Fiškálna decentralizácia a obce”, Conservative Institute M. R. Štefánika, (2005):3. November 03, 2017 http://www.konzervativizmus.sk/ upload/pdf/fisk_dec.pdf 
fiscal impact on municipality caused by departure of the existing and potential economically active population followed by many other problems.

Another problem that might arise is the misuse of powers when determining the level of local taxes paid by taxpayers. Self-government bodies should make every effort to collect required amount of tax revenues to the budget in time as it is granted with almost total freedom in introducing and levying various types of local taxes. Self-government is allowed both to increase or reduce the basic tax rate, which must not exceed the maximum limit, as defined by the Act on local taxes. In practice, self-government bodies might decide to levy the highest tax rate to maximise its budget revenue, leading to an excessive taxation and consequent inability of taxpayers to pay their duties.

A further problem is the number of shared functions as it is difficult to make a clear distinction between the competencies assigned to state and the competencies of self-government and their accountability to citizens. The fact that political and executive functions have not been clearly defined since the beginning of the decentralisation process, makes it even more difficult. The most serious perceived deficiency is that higher territorial units were created regardless of the geographical zones and, thus, the problem with appointment of political nominees of the ruling parties into the functions applies also to self-government ${ }^{32}$.

The problem that still, today, represents an ongoing challenge, linked not only to fiscal decentralisation, but also to public administration and provision of the public service, is the issue of fragmented settlement structure of towns and villages characterized by a large number of municipalities of low population density. Given that currently there are 2,933 municipalities in the Slovak republic ${ }^{33}$, we can assume that administrative organisation of the country is over-fragmented which results in ineffective municipal expenditure system, problems connected to effective provision of high-quality service, and limited possibility for municipality to be funded

32 Nižňanský Viktor, Hamalová Marta, “Decentralizácia a Slovensko” (2013):67. November 05, 2017 http://www.komunal.eu/images/Decentraliz\%C3\%A1cia_a_Slovensko.pdf

33 Government Office of the Slovak Republic, "Information about Slovak republic" (2017). October 20, 2017 http://www.vlada.gov.sk/slovensko/ 
by the budget of the European Union ${ }^{34}$. In order to have a better and more precise picture of this phenomenon, here are some basic information regarding the actual situation in the Slovak republic ${ }^{35}$ :

- $92 \%$ of the total number of municipalities has less than 3000 residents;

- 138 municipalities out of the total number of municipalities in Slovakia have less than 99 inhabitants and more than 200 municipalities have population of less than 500 (according to the statistics at the end of 2016);

- municipalities with less than 250 inhabitants spend half of their expenses on administration;

- in Slovakia, the average number of inhabitants per municipality is three times lower than the average of other European Union countries, and five times lower than the average of OECD countries;

- there are three times more mayors in Slovakia in comparison with other countries of the European Union;

- countries with similar size and number of inhabitants to Slovakia have 26 times more self-administration units.

\section{CONCLUSIONS}

The problems regarding local self-government have not been solved yet despite the fiscal decentralisation reform. Legislation defines the notion of

34 Černěnko Tomáš, Havran Peter, Kubala Jozef. "Skrytý poklad v samospráve. Alternatívne možnosti sústredenia výkonu správy v samosprávach. "Ekonomická analýza 41" (2017):7-20. November 04, 2017: https://sekarl.euba.sk/arl-eu/sk/csg/?repo=eurepo\&key $=86591941668$

35 Statistical office of the Slovak Republic, "Demography and social statistics, Population and migration, Size Groups of Municipalities - SR, Areas, Regions, Districts, Urban, Rural". October 20, 2017 http://statdat.statistics.sk/cognosext/cgi-bin/cognos.cgi?b_action=cognosViewer\&ui.action=run\&ui.object=storeID $(\% 22 \mathrm{i} 0 \mathrm{C} 852 \mathrm{CAA} 5451437 \mathrm{C} 92774 \mathrm{D}-$ B33EC08675\%22) \&ui.name=Size $\% 20$ Groups $\% 20$ of\%20Municipalities $\% 20-\% 20$ SR\%2c\%20Areas\%2c\%20Regions\%2c\%20Districts\%2c\%20Urban\%2c\%20Rural\%20 $\% 5$ bom $7023 \mathrm{rr} \% 5 \mathrm{~d} \&$ run.outputFormat=\&run.prompt=true \&cv.header=false \&ui.backUR$\mathrm{L}=\% 2 \mathrm{f}$ cognosext $\% 2 \mathrm{fcps} 4 \% 2$ fportlets $\% 2$ fcommon $\% 2$ fclose.html 
municipality as an independent territorial and administrative unit whose main function is taking care of development of its territory and needs of its citizens ${ }^{36}$.

As proved by the above-mentioned research on municipality, such a definition gives rise to many questions, since it neither regulates nor specifies the exercise of this function in relation to the size of municipality. Therefore, in theory, a municipality with 23 permanent residents (Poproč) should take care of development of its territory and needs of its citizens in the same way as a municipality that has a population of 8000 (Smižany). These findings suggest that demographic factors need to be considered as they affect the functioning of municipality and they play an important role in its policy-making processes.

Evidently, a large part of the municipality's budget is spent on administrative expenses, in particular, costs on functioning of the municipal office or salary costs of mayor or local deputies. Moreover, capital expenditure of municipality is also limited and municipality, thus, cannot invest in its development and a large number of public posts in local self-government is vacant.

With regard to the above-mentioned, it is difficult for municipality to support projects co-funded from European Union budgets and, therefore, municipality has restricted access to access to external financial resources. A large number of municipalities of low population still represents the major factor that reduces the overall efficiency of providing public interest services. Possible solution would be merging small municipalities into bigger and economically more advanced units, as it was the main goal of fiscal decentralisation ${ }^{37}$. Under the assumption that municipality has been continuously loss-making, and its poor financial situation remains unresolved or, indeed, deteriorates, it should look for best practices and principles of the effective municipal administration, while the needs of its citizens should be at the core of all its endeavours.

Notwithstanding positive or negative sides of fiscal centralisation, municipality is responsible for the quality of life within its territory

36 Article $1 \$ 1(1-2)$ of Act on Municipalities.

37 Sedláková Slávka, "Fiškálna decentralizácia - jej význam a dôsledky pre územnú samosprávu“, National and regional economics VII. (2008): 810. DOI: http://www3.ekf. tuke.sk/konfera2008/zbornik/files/prispevky/sedlakova.pdf 
and its decisions affect every citizen without distinction. Bearing this in mind, we consider the best solution to be the one that places the most importance on the care of its citizens even at the cost of merger of municipalities.

The overall situation might be improved by new division of powers and competences based on the analysis of conditions of a given municipality, in addition to the mentioned possibility of merger into economically stronger units. The proposed solution for the situation when municipality cannot perform its tasks would be legally required cooperation and division of allocated competences between municipality, which does not have to face very basic problems and has the capacity to fulfil its public service obligations, and other levels of public administration.

Another problem is regarding the Act on Municipalities, adopted more than 25 years ago, which despite the fact that it has gone through 49 amendments since that time, it did not have the expected impact. Despite the partial changes remained a lot of ambiguities, which don't contribute to a sense of legal certainty.

\section{REFERENCES}

Čavojec, Jozef, Sloboda Dušan. 2005. "Fiškálna decentralizácia a obce. "Conservative Institute M. R. Štefánika". November 03, 2017 http://www.konzervativizmus.sk/upload/pdf/fisk_dec.pdf

Černěnko, Tomáś, Havran, Peter, Kubala, Jozef. 2017. "Skrytý poklad v samospráve. Alternatívne možnosti sústredenia výkonu správy v samosprávach. "Ekonomická analýza 41". November 04, 2017 DOI: https://sekarl.euba.sk/ arl-eu/sk/csg/?repo=eurepo\&key=86591941668

Ebel, Robert, Yilmaz, Serdar. 2004. "Concept of fiscal decentralization and worldwide overview. "World Bank Institute Course Intergovernmental Relations \& Local Financial Management World Bank" 1-33. DOI: https://www. researchgate.net/publication/253798443_Concept_of_fiscal_decentralization_and_worldwide_overview_World_Bank_Institute

Hendrych, Dušan a kol. 2006. Správní právo, obecná čast. Praha: C.H.Beck.

Horváthová, Lenka. 2009. "Dopad fiškálnej decentralizácie na miestne rozpočty v SR. "Teoretické a praktické aspekty veřejných financi". DOI: http://kvf.vse. cz/storage/1239723298_sb_horvathova.pdf 
Hughes, Owen, E. 2003. "Public management and administration, an Introduction". October 22, 2017 https://www.academia.edu/15157168/PUBLIC_ MANAGEMENT_OR_PUBLIC_ADMINISTRATION

Klimovský, Daniel. 2014. Základy verejnej správy. Bratislava: Wolters Kluwer SK. Machajová, Jozefína a kol. 2007. Všeobecné správne právo. Bratislava: Poradca podnikatela, spol. s.r.o.

Maruchnič Ján, Čunderlík Lubomír. 2005. ”Fiškálna decentralizácia v Slovenskej republike. "Medzinárodní a srovnávací právní revue" 14:64-72. DOI: http:// iclr.upol.cz/wp-content/uploads/2011/03/14_Maruchnic_Jan-Cunderlik_ Lubomir-64-77.pdf

Nižňanský, Viktor, Hamalová, Marta. 2013. “Decentralizácia a Slovensko” November 05, 2017 http://www.komunal.eu/images/Decentraliz\%C3\%A1cia_a_Slovensko.

Palúš, Igor, Jesenko, Michal, Olexa, Lukáš, Ondrová, Júlia. 2016. Ústavné právo Slovenskej republiky. Košice: UPJŠ Košice.

Palúš, Igor. 2002. Štátne právo porovnávacie. Košice: UPJŠ Košice.

Sedláková, Slávka. 2008. "Fiškálna decentralizácia - jej význam a dôsledky pre územnú samosprávu. "National and regional economics VII". 805-810. DOI: http://www3.ekf.tuke.sk/konfera2008/zbornik/files/prispevky/sedlakova.pdf

Sivák, Rudolf. 2015. Financie. Bratislava: Wolters Kluwer.Škultéty, Peter, Kaššák Rastislav. 2014. Správne právo hmotné, všeobecná čast́. Bratislava: Veda.

Sládeček, Vladimír. 2005. Obecné správní právo. Praha: Wolters Kluwer.

Tej, Juraj. 2011."Správa a manažment”. October 23, 2017 http://www.pulib.sk/ elpub2/FM/Tej2/index.html. 